DOI: 10.1515/LPTS-2015-0034

\title{
EFFICIENT USE OF COGENERATION AND FUEL DIVERSIFICATION
}

\author{
M. Kunickis, M. Balodis, U. Sarma, A. Cers, O. Linkevics \\ Latvenergo AS, 12 Pulkveža Brieža Str., Riga, LV-1230, LATVIA \\ e-mail: maris.kunickis@latvenergo.lv
}

Energy policy of the European Community is implemented by setting various goals in directives and developing support mechanisms to achieve them. However, very often these policies and legislation come into contradiction with each other, for example Directive 2009/28/EC on the promotion of the use of energy from renewable sources and Directive 2012/27/EU on energy efficiency, repealing Directive 2004/8/EC on the promotion of cogeneration based on a useful heat demand.

In this paper, the authors attempt to assess the potential conflicts between policy political objectives to increase the share of high-efficiency cogeneration and renewable energy sources (RES), based on the example of Riga district heating system (DHS).

If a new heat source using biomass is built on the right bank of Riga DHS to increase the share of RES, the society could overpay for additional heat production capacities, such as a decrease in the loading of existing generating units, thereby contributing to an inefficient use of existing capacity.

As a result, the following negative consequences may arise: 1) a decrease in primary energy savings (PES) from high-efficiency cogeneration in Riga DHS, 2) an increase in greenhouse gas (GHG) emissions in the Baltic region, 3) the worsening security situation of electricity supply in the Latvian power system, 4) an increase in the electricity market price in the Lithuanian and Latvian price areas of Nord Pool power exchange.

Within the framework of the research, calculations of PES and GHG emission volumes have been performed for the existing situation and for the situation with heat source, using biomass. The effect of construction of biomass heat source on power capacity balances and Nord Pool electricity prices has been evaluated.

Keywords: biomass boiler, combined heat and power plant, high-effciency cogeneration.

\section{INTRODUCTION}

The European Community's energy policy is implemented by means of directives setting various goals and outlining the mechanisms to achieve them. However, these objectives frequently are not mutually balanced and conflict with one another. There is, for example, a conflict between the objectives in Directive 2009/28/EC 
on the promotion of the use of energy from renewable sources [1] and Directive 2012/27/EU on energy efficiency [2], which repeals Directive 2004/8/EC on the promotion of cogeneration based on a useful heat demand [3].

In this paper, the authors evaluate the possible conflicts between the objectives of increasing the share of high-efficiency cogeneration and renewable energy using the example of Riga district heating system (DHS).

The construction of a new heating source based on biomass for Riga DHS networks on the right bank of the Daugava river with the goal of increasing the use of renewable sources would lead to the public overpayment for additional generation capacities due to the decreased load on the existing production facilities, thus facilitating the inefficient use of the existing capacities.

In such a case, Riga DHS would see a fall in primary energy savings (PES) from the use of high-efficiency cogeneration, while in the Baltic region the increasing output of oil shale power plants would lead to increased greenhouse gas (GHG) emissions, freezing the capacities of the combined cycle gas turbine (CCGT) units. Moreover, Latvia's electricity supply security would deteriorate drastically, and electricity prices on the Nord Pool electricity exchange would be expected to rise for the Latvian and Lithuanian price regions.

In this paper, the authors seek to answer whether this would be an adequate price to be paid by Latvian electricity users and the entire society for a comparatively small benefit of the users of thermal energy from Riga DHS.

As part of this study, calculations of PES and GHG emissions were performed for the current situation and a scenario employing a new biomass heating source. The effect the potential new heating source may possibly have on electrical capacity balance and electricity prices on the Nord Pool exchange was also assessed.

\section{CURRENT SITUATION}

Until 2008, thermal energy was supplied to the heating networks on the right bank of Riga city mainly by combined heat and power plants of Latvenergo JSC. However, recent years have seen an increasing number of heating source construction projects aimed at the redistribution of thermal load that is usable in cogeneration. The first such project was carried out in 2008 by Juglas Jauda Ltd that constructed a natural gas-fired combined heat and power plant operated by internal combustion engines in the supply territory of Riga CHPPs. This plant currently has an electrical capacity of $14.9 \mathrm{MW}_{\mathrm{el}}$ and thermal capacity of $16 \mathrm{MW}_{\mathrm{th}}$.

Ideas of various interested parties for even further reduction of the load on Riga combined heat and power plants through the construction of high-capacity boiler plants that use renewable energy sources are currently at the exploratory stage.

Meanwhile, since 2000, Latvenergo JSC has been constantly modernising and reconstructing its generating capacities with the goal of using Riga's thermal capacity with maximum efficiency in an efficient cogeneration process. The 2 nd stage of the reconstruction of Riga TEC-2 was completed in late 2013, with the company receiving new high-efficiency cogeneration power plants with a total electrical capacity of $965 \mathrm{MW}_{\mathrm{el}}$ and thermal capacity of 1,615 $\mathrm{MW}_{\mathrm{th}}$. The primary fuel used by 
Riga combined heat and power plants is natural gas, and diesel is used as a backup fuel [4].

In the current market situation with comparatively high natural gas prices and low biomass prices, boiler plants that use biomass can compete with natural gas-fired generating sources in terms of thermal energy production, provided that this market is viewed separately from the electricity market and separately from the GHG limiting objectives on a broader scope. It is difficult to predict how long this market conjuncture will persist, which will undoubtedly have an effect on the load on cogeneration plants, their competitiveness on the electricity market, as well as the prices in the Nord Pool Latvian and Lithuanian price regions.

\section{IMPACT OF THE BIOMASS UNIT ON COMBINED CYCLE UNITS}

The addition of a boiler plant using renewables to the heating networks on the right bank of Riga city will create a significant decrease in the use and load of the existing combined cycle (CCGT) power units. Redistribution of the existing heating load in favour of the new heating source will mean decreased use of the CCGT facilities in the cogeneration mode and, consequently, the amount of electricity generated at lower cost will also decrease. This impact will be especially pronounced during periods of low demand for heating and at electricity market prices that are lower than the cost of electricity generation through condensation. In this case, the production of thermal energy by CCGT power units would decrease by $631 \mathrm{GWh}$, electricity production by $1,063 \mathrm{GWh}$, and fuel consumption by 2,249 GWh [5]. More detailed information about production volumes in the current situation and in the scenario with a new biomass heating source is presented in Table 1 (WHB here - water heating boilers).

Table 1

Impact of the Biomass Unit on Combined Cycle (CCGT) Units, MWh

\begin{tabular}{|l|l|l|l|l|}
\hline MWh & CCGT & WHB & Alternative & Total \\
\hline & \multicolumn{4}{l|}{ Current situation } \\
\hline
\end{tabular}

The shortage in electricity could be covered by importing it or by operating Riga TEC-2 in the condensation mode, which would, in turn, increase the price of electricity in Nord Pool Latvian and Lithuanian price regions. 


\section{DECREASE IN RIGA DHS ENERGY EFFICIENCY}

If a new heating source were constructed for the heating networks on the right bank of Riga city in a zone of existing high-efficiency cogeneration heating supply, it would undoubtedly decrease the opportunities of using cogeneration capacities and, thus, the energy efficiency of this district heating system.

The overall efficiency of a cogeneration cycle (fuel use factor) can be expressed using this well-known formula:

$$
\eta_{T E C}=\frac{E_{T E C}+H_{T E C}}{B_{T E C}},
$$

where $H_{T E C}$ is amount of useful heat produced in the cogeneration mode; $E_{T E C}-$ electricity from cogeneration; $B_{T E C}-$ fuel consumption by cogeneration equipment.

The ratio between electricity and heat $(\mathrm{C})$ is the ratio between electricity and useful heat produced in the cogeneration mode:

$$
C=\frac{E_{T E C}}{H_{T E C}} .
$$

Efficiency reference value for separate production $\left(\mathrm{RefH}_{\eta}\right.$ and $\left.\operatorname{RefE}_{\eta}\right)$ is the efficiency of the alternative separate heat and electricity production to be replaced by cogeneration.

Energy production by a natural gas-fired cogeneration plant, for example, is compared with the production of thermal energy by a gas boiler with a $90 \%$ efficiency factor and electricity generation by a combined cycle power unit with a $52 \%$ efficiency factor.

However, for the purposes of this study, we will compare the energy output of CCGTs with heat production by a biomass boiler (with an $86 \%$ efficiency factor) and electricity generation by an oil shale power unit (36\%), because these are real alternatives in the Baltic energy system.

High-efficiency cogeneration is cogeneration that allows for primary energy resource savings of more than $10 \%$ compared to separate production (PES $\geq 10 \%)$. Primary energy savings are calculated as follows:

$$
P E S=\left(1-\frac{1}{\frac{T E C H_{\eta}}{r e f H_{\eta}}+\frac{T E C E_{\eta}}{r e f E_{\eta}}}\right) \times 100 \%,
$$

where $P E S$ are primary energy savings; $T E C H_{\eta}$ - heat efficiency; $T E C E_{\eta}$ - electricity efficiency. 
$T_{E C H}$ and $T E C E_{\eta}$ in the cogeneration mode are expressed as the ratio between the amount of useful heat or electricity produced annually and the amount of fuel used to produce the total amount of useful heat and electricity in the cogeneration mode:

$$
T E C H_{\eta}=\frac{H_{T E C}}{B_{T E C}} \quad T E C E_{\eta}=\frac{E_{T E C}}{B_{T E C}}
$$

The overall efficiency of the cogeneration cycle can be obtained by adding the efficiency values for thermal energy and electricity production:

$$
\eta_{T E C}=T E C H_{\eta}+T E C E_{\eta}
$$

As part of the study, calculations of the primary energy savings (PES) were performed for the current situation (with a CCGT power unit) in comparison with a scenario of producing heat by a biomass boiler and generating electricity by oil shale power plants (Table 2). The decrease in the CCGT unit energy output due to the installation of a biomass boiler, i.e. $631 \mathrm{GWh}$ of heat and $1063 \mathrm{GWh}$ of electricity (gross), is taken into account.

Table 2

\section{Calculation of PES for a CCGT Power Unit in Comparison}

\begin{tabular}{|c|c|c|}
\hline Amount of useful heat produced in the cogeneration mode, GWh & $\mathrm{H}_{\mathrm{TEC}}$ & 631 \\
\hline Electrical capacity of the power unit, MW & $\mathrm{P}$ & 419 \\
\hline Thermal capacity of the power unit, MW & Qccgt & 270 \\
\hline Normative electrical to thermal capacity ratio & $\mathrm{C}_{\text {norm }}$ & 1.552 \\
\hline Actual electricity (net) to thermal energy output ratio & $\mathrm{C}_{\text {fakt }}$ & 1.260 \\
\hline Cogeneration electricity (net), GWh & $\mathrm{E}_{\mathrm{TEC}}$ & 795 \\
\hline Actual electricity output (net), GWh & $\mathrm{E}_{\text {fakt }}$ & 1030 \\
\hline Condensation electricity (net), GWh & $\mathrm{E}_{\text {kond }}$ & 235 \\
\hline Total fuel consumption & $\mathrm{B}_{\text {kopā }}$ & 2249 \\
\hline Fuel consumption in the cogeneration mode & $\mathrm{B}_{\mathrm{TEC}}$ & 1778 \\
\hline Heat efficiency, $\%$ & $\mathrm{TECH}_{\eta}$ & $35 \%$ \\
\hline Electricity efficiency, \% & $\mathrm{TECE}_{\eta}$ & $45 \%$ \\
\hline Overall efficiency, \% & $\eta_{\mathrm{TEC}}$ & $80 \%$ \\
\hline Reference efficiency indicator (heat, biomass boiler), $\%$ & 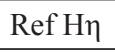 & $86 \%$ \\
\hline Reference efficiency indicator (electricity, oil shale), $\%$ & 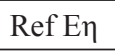 & $36 \%$ \\
\hline Fuel consumption by separate production of electricity and heat, GWh & $\mathrm{B}_{\mathrm{H}+\mathrm{E}}$ & 2942 \\
\hline Savings, GWh & $\Delta \mathrm{B}$ & 1164 \\
\hline Primary energy resource savings & PES & $39.6 \%$ \\
\hline
\end{tabular}
with a Biomass Boiler and an Oil Shale Power Unit

According to Table 2, we can conclude that, when comparing energy production by a CCGT power unit with a biomass boiler and an oil shale unit, primary energy resource savings amount to $39.6 \%$ or $1,164 \mathrm{GWh}$.

Analysis of statistics data over the period of 2000-2013 on Riga CHP plants using the method explained above (in comparison with separate production by a 
biomass boiler and an oil shale unit) allows establishing that average fuel savings before the reconstruction of Riga CHP plants amounted to $\sim 1400 \mathrm{GWh}$, growing to $1600-3200 \mathrm{GWh}$ after the reconstruction (Fig. 1).

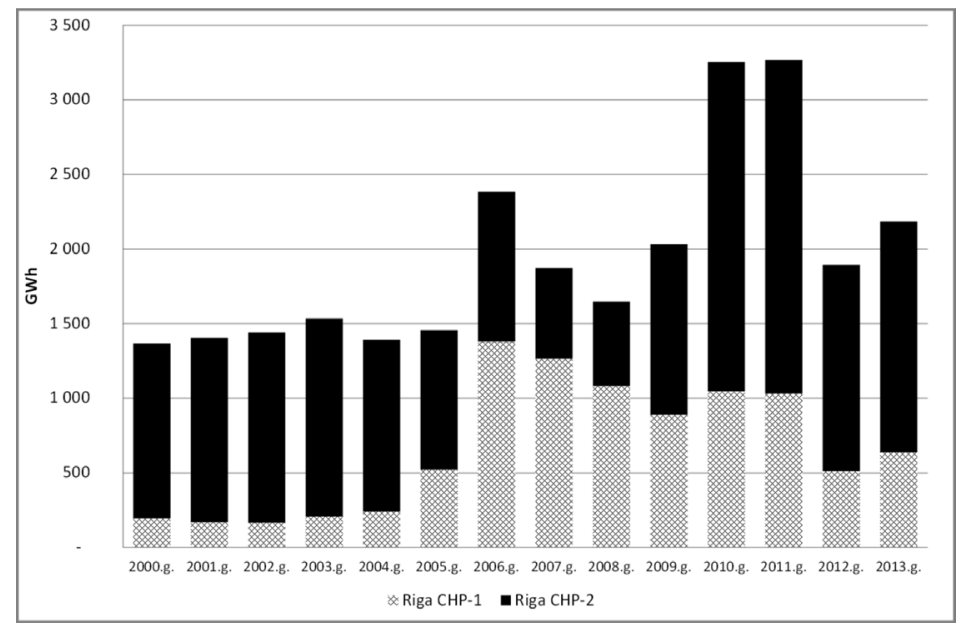

Fig. 1. Fuel savings at Riga CHP plants.

\section{INCREASE IN GHG EMISSIONS}

It is formally accepted that the use of biomass is neutral in terms of GHG emissions. Therefore, the calculated GHG emissions for the production of thermal energy would be decreased by the construction of a biomass-fired heating source for the heating networks on the right bank of Riga city. However, considering that electricity generated by combined cycle power units would in this case be substituted with electricity generated by power plants in Narva (with 4-5 times larger specific $\mathrm{CO}_{2}$ emissions), the total amount of GHG emissions will increase. This is illustrated comparing specific GHG emissions in electricity production by Riga TEC-2 and the ones produced by the combined heat and thermal power plants (TPP) of Narva (Fig. 2).

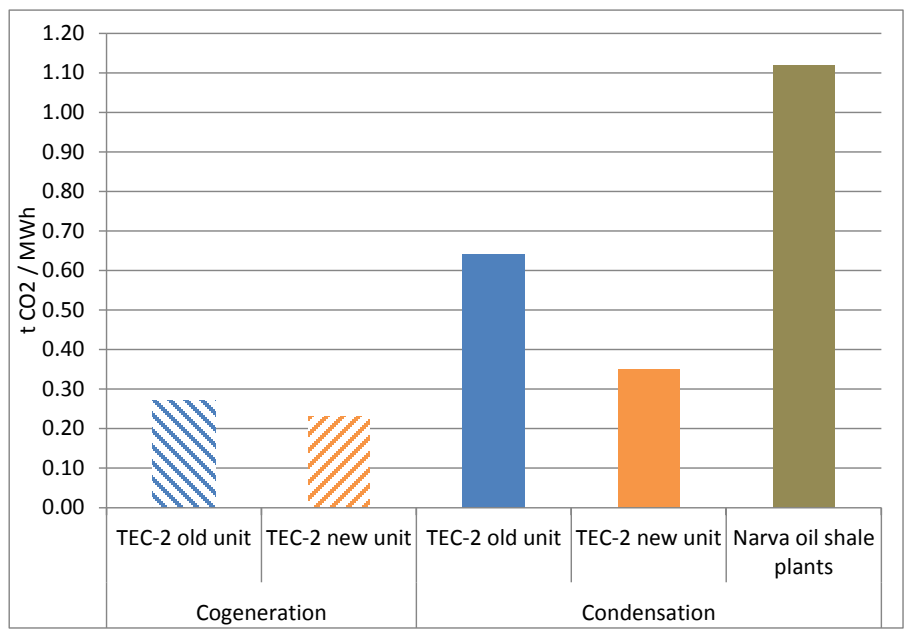

Fig. 2. Comparison of GHG emissions by Riga TEC-2 and Narva CHPPs. 
We will then calculate the GHG emissions for the current situation with operating combined cycle (CCGT) power units of Riga TEC-2 and for the scenario with the construction of a biomass boiler, replacing the electricity output of CCGT with electricity produced by Narva TPPs. Calculation of GHG emissions is provided in Table 3.

In case of construction of a biomass boiler, overall GHG emission volumes could possibly increase by 500-660 thousand tonnes (Table 3 ). The main reason of GHG increase is electricity production in Narva TPP to replace CCGT.

Table 3

Calculation of GHG Emissions

\begin{tabular}{|c|c|c|}
\hline Mode & Mixed mode & Cogeneration \\
\hline Decrease in CCGT energy output, GWh & 1661 & 1426 \\
\hline thermal energy & 631 & 631 \\
\hline electricity (in the cogeneration mode) & 795 & 795 \\
\hline electricity (in the condensation mode) & 235 & - \\
\hline Decrease in CCGT fuel consumption, GWh & 2249 & 1778 \\
\hline \multicolumn{3}{|l|}{ Efficiency factor, $\%$} \\
\hline Biomass boiler & $86 \%$ & $86 \%$ \\
\hline Oil shale power unit & $36 \%$ & $36 \%$ \\
\hline \multicolumn{3}{|l|}{ Fuel consumption, GWh } \\
\hline Biomass boiler & 734 & 734 \\
\hline Oil shale power unit & 2861 & 2208 \\
\hline \multicolumn{3}{|l|}{ Specific GHG emissions, t/MWh } \\
\hline CCGT & 0.205 & 0.205 \\
\hline Biomass boiler & 0.000 & 0.000 \\
\hline Oil shale power unit & 0.392 & 0.392 \\
\hline \multicolumn{3}{|l|}{ Total GHG emissions, $\mathrm{t}$} \\
\hline CCGT & 461045 & 364490 \\
\hline Biomass boiler & - & - \\
\hline Oil shale power unit & 1121512 & 865536 \\
\hline Biomass and oil shale & 1121512 & 865536 \\
\hline Increase in GHG emissions & 660467 & 501046 \\
\hline
\end{tabular}

\section{DETERIORATION OF ELECTRICITY SUPPLY SECURITY}

According to the 2014 annual report of the Transmission System Operator (TSO), Latvia's energy system is unable to ensure the necessary electricity supply security without the combined cycle power units of Riga TEC-2. The annual report of the TSO indicates [6]: "Analysing the capacity adequacy for the coming years, the conservative scenario (A) of capacity (MW) adequacy analysis tables shows that the generating capacity is insufficient to cover the Latvian electricity peak load during winter months, not only currently, with the construction of Riga TEC-2 second stage 
already completed (439 MW), but also until 2024, when wind power plants with a net capacity of $454 \mathrm{MW}$ are envisioned."

Comparison in terms of electricity system capacity balance was performed to examine both the current situation and the scenario with the possible new heating source and mothballing of the combined cycle power units (Table 4).

Four possible scenarios are examined in Table 4: 1) without a biomass boiler, 2) biomass boiler replaces one CCGT unit, 3) biomass boiler replaces two CCGT units, 4) all power units of Riga CHPPs are stopped.

In these scenarios, the capacity deficit grows from 301 to $1,290 \mathrm{MW}$ and, accordingly, the adequacy of generation capacity will reduce from $80 \%$ to $16 \%$.

Capacity Balance Assessment

\begin{tabular}{|c|l|l|l|l|}
\hline Scenario & 1 & 2 & 3 & 4 \\
\hline Maximum load, MW & 1543 & 1543 & 1543 & 1543 \\
\hline Capacity of high-capacity power plants, MW & 2612 & 2187 & 1762 & 1623 \\
\hline incl. Daugava HPPs & 1581 & 1581 & 1581 & 1581 \\
\hline incl. Riga and Imanta CHPPs & 1031 & 606 & 181 & 42 \\
\hline Capacity of small power plants, MW & 547 & 547 & 547 & 547 \\
\hline incl. natural gas-fired CHPPs & 113 & 113 & 113 & 113 \\
\hline incl. small hydro, wind and solar PPs & 293 & 293 & 293 & 293 \\
\hline incl. biomass and biogas plants & 141 & 141 & 141 & 141 \\
\hline Available capacity, MW & 1461 & 1036 & 611 & 472 \\
\hline Required reserves, MW & 219 & 219 & 219 & 219 \\
\hline Capacity deficit & -301 & -726 & -1151 & -1290 \\
\hline Adequacy of generation capacity & $80 \%$ & $53 \%$ & $25 \%$ & $16 \%$ \\
\hline
\end{tabular}

If a biomass boiler replaces a CCGT unit in Riga CHP (2 scenario), a substantial capacity deficit will be expected in January 2020. It could deteriorate the security of electricity supply in Latvia.

\section{EFFECT ON ELECTRICITY MARKET PRICE}

The availability of Riga TEC-2 and the cost of electricity production determine the prices of electricity in the Baltics. With fewer opportunities of trading thermal energy produced in the cogeneration mode, the price of electricity in the region will increase and the competitiveness of energy-intensive industries as well as the expected state revenue will suffer.

This situation is illustrated in Fig. 3. If a biomass boiler is constructed, electricity production of Riga CHP-2 CCGT units in the cogeneration mode will reduce. In this case, the market equilibrium price will move to the next more expensive generator, which is CCGT in the condensing mode. The market price will increase by the value equal to the difference between CCGT prices in cogeneration and condensing modes. 


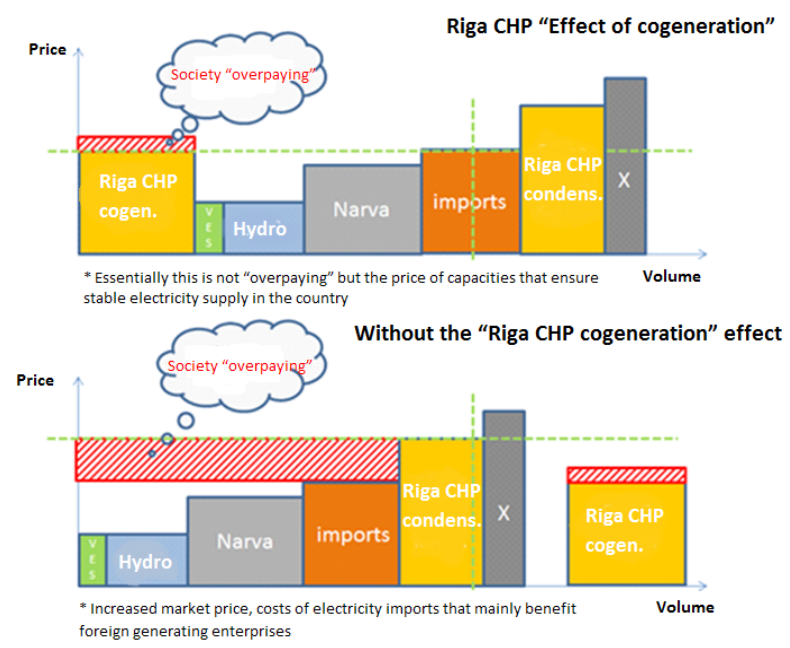

Fig. 3. Conjuncture and principles of operation of the electricity market.

Forecasting of electricity prices in the Latvian and Lithuanian price regions of the Nord Pool exchange was performed in this study for the current situation and the scenario with the new heating source and mothballing of the combined cycle power units.

The construction of a biomass boiler will, in fact, disable the cogeneration option for combined cycle units (CCGT) to generate relatively cheap (by $\sim 40 \%$ ) electricity during the non-heating period (May - September). At present moment generation does not cause losses to Latvenergo JSC, because the capacities of Riga CHPPs are paid by the Mandatory Procurement Component. It will significantly increase the electricity market price in Latvia, if Latvia shifts to the dominant operation in the condensation mode.

As a result of the replacement of relatively cheap CCGT electricity by more expensive power, an overall negative effect on power consumers could be 17 million $€$ per year (Table 5).

Table 5

Comparison of Electricity Production Cost when Operating a CCGT in Cogeneration \& Condensation Modes

\begin{tabular}{|l|l|l|l|l|l|l|}
\hline \multirow{2}{*}{ Month } & Nord Pool & Cogen. & Conden. & Deviation* & Volume & Losses \\
\cline { 2 - 7 } & $€ / \mathrm{MWh}$ & $€ / \mathrm{MWh}$ & $€ / \mathrm{MWh}$ & $€ / \mathrm{MWh}$ & MWh & $€$ \\
\hline January & 42.95 & 43.9 & 67.8 & 24.9 & 77108 & 1917590 \\
\hline February & 42.73 & 43.3 & 67.0 & 24.2 & 71739 & 1739538 \\
\hline March & 41.59 & 43.2 & 66.7 & 25.1 & 51028 & 1281670 \\
\hline April & 44.07 & 43.0 & 66.4 & 22.4 & - & - \\
\hline May & 51.49 & 42.9 & 66.3 & 14.8 & 130200 & 1931774 \\
\hline June & 54.9 & 43.0 & 66.5 & 11.6 & 126175 & 1464625 \\
\hline July & 57.34 & 44.0 & 68.0 & 10.7 & 130200 & 1392617 \\
\hline August & 55.31 & 44.1 & 68.1 & 12.8 & 130200 & 1663989 \\
\hline September & 58.36 & 44.1 & 68.2 & 9.8 & 125825 & 1235704 \\
\hline October & 63.7 & 45.1 & 69.7 & 6.0 & 61360 & 370876 \\
\hline November & 51.13 & 45.2 & 69.8 & 18.7 & 48134 & 900334 \\
\hline December & 43.77 & 45.2 & 69.9 & 26.2 & 111187 & 2908124 \\
\hline Total & & & & & 1063157 & 16806842 \\
\hline
\end{tabular}

* - Deviation of the market price 


\section{CONCLUSIONS}

The construction of a new heating source for heating networks on the right bank of Riga city could have the following consequences:

- It could possibly lead to a decrease in primary energy savings (PES) from the use of high-efficiency cogeneration by approximately $40 \%$ or 1,164 GWh.

- In the Baltic region, through the increased output of oil shale power plants, greenhouse gas (GHG) emissions would increase by 500-660 thousand tonnes in comparison with output of high-efficiency cogeneration.

- Mothballing of the combined cycle power unit (CCGT) capacities could lead to the deterioration of electricity supply security in the Latvian energy system with reduction in adequacy of generation capacity from $80 \%$ to $16 \%$.

- Electricity price could increase in the Latvian and Lithuanian price regions of the Nord Pool electricity exchange. Overall negative effect on power consumers could account for about 17 million $€$.

\section{REFERENCES}

1. Eiropas Parlamenta un Padomes direktīva 2009/28/EK par atjaunojamo energoresursu izmantošanas veicināšanu un ar ko groza un sekojoši atcel Direktīvas 2001/77/EK un 2003/30/EK. 2009. gada 23. aprīlis.

2. Eiropas Parlamenta un Padomes direktīva 2012/27/ES par energoefektivitāti, ar ko groza Direktīvas 2009/125/EK un 2010/30/ES un atcel̦ Direktīvas 2004/8/EK un 2006/32/EK. 2012. gada 25. oktobris.

3. Eiropas Parlamenta un Padomes direktīva 2004/8/EK par tādas koǵenerācijas veicināšanu, kas balstīta uz lietderīgā siltuma pieprasījumu iekšējā enerǵijas tirgū, un ar kuru groza Direktīvu 92/42/EEK. 2004. gada 11. februāris.

4. Efektīvi un atbildīgi saražotā elektroenergỉja (2014). Rīga: Latvenergo AS.

5. Rīgas TEC-1 un TEC-2 (2014). Efektivitātes paaugstināšanas un kurināmāa diversifikācijas iespēju izpēte. Rīga: Latvenergo AS.

6. Pārvades sistēmas operatora ikgadējais novērtējuma ziņojums (2014). AST.

7. Loo, S., and Koppejan J. (2009). The Handbook of Biomass Combustion and Co-firing. London: Earthscan

8. Galiņš A., Laizāns A., Kanceviča L. (2008). Alternatīvās energétikas iekārtas. Jelgava: LLU, 316 lpp. 


\title{
KOĢENERĀCIJAS EFEKTĪVA IZMANTOŠANA UN KURINĀMĀ DIVERSIFIKĀCIJA
}

\author{
M. Kunickis, M.Balodis, U.Sarma, A.Cers, O. Linkevičs
}

\section{Kopsavilkums}

Eiropas Kopienas energêetikas politika tiek īstenota, ar direktīiām nosakot dažādus mērksus un iezīmējot mehānismus to sasniegšanai. Taču nereti šie uzstādījumi nav savstarpēji līdzsvaroti un nonāk zināmās pretrunās viens ar otru. Piemēram, pretruna veidojas starp uzstādījumiem direktīvā 2009/28/EK par atjaunojamo energoresursu izmantošanas veicināšanu un direktīvā 2012/27/ES par energoefektivitāti, kas atcel̦ direktīvu 2004/8/EK par tādas koǵenerācijas veicināšanu, kas balstīta uz lietderīgā siltuma pieprasījuma.

Šajā publikācijā autori izvērtē iespējamas kolīzijas un pretrunas starp mērķiem palielināt augsti efektīvas koǵenerācijas un atjaunojamās enerǵijas îpatsvaru uz Rīgas centralizētās siltumapgādes sistēmas (CSS) piemēra.

Ja Rīgas pilsētas CSS laba krastā siltumtīklos, ar mērķi palielināt atjaunojamo resursu izmantošanas apjomus, tiktu uzbūvēts jauns biomasu izmantojošs siltuma avots, sabiedrība pārmaksātu par papildus ražošanas jaudām, jo samazinātos esošo ražošanas iekārtu noslodze, tādējādi veicinot esošo jaudu neefektīvu izmantošanu.

Tādā gadījumā, Rīgas CSS samazinātos primāras enerğijas ietaupījums (PEI) no augsti efektīvas koǵenerācijas, bet Baltijas reǵionā kopumā, pieaugot degakmens elektrostaciju izstrādei, palielinātos siltumnīcefekta gāzu (SEG) emisijas, iekonservējot kombinētā cikla energobloku (CCGT) jaudas, krasi pazeminātos Latvijas elektroapgādes drošums, un Nord Pool elektroenerǵijas biržas Latvijas un Lietuvas cenu apgabalos būtu sagaidāms elektroenerǵijas cenas pieaugums.

Izpētes ietvaros tika veikti PEI un SEG emisijas aprēķini esošai situācijai un gadījumam, ja tiek uzbūvēts biomasas siltuma avots. Tika izvērtēta arī potenciālā siltuma avota iespējamā ietekme uz elektriskās jaudas bilancēm un Nord Pool biržas elektroenerǵijas cenām.

26.09.2015. 